\title{
IBN KHALDUN MODEL ON POVERTY: THE CASE OF ORGANIZATION OF ISLAMIC CONFERENCE (OIC) COUNTRIES
}

\author{
Ahlis Fatoni ${ }^{1}$, Sebastian Herman ${ }^{2}$ and Adam Abdullah ${ }^{3}$ \\ ${ }^{1}$ International Islamic University Malaysia, Malaysia, ahlisfatoni@gmail.com \\ ${ }^{2}$ Tazkia University College of Islamic Economics, Indonesia, sebastianherman@tazkia.ac.id \\ ${ }^{3}$ International Islamic University Malaysia, Malaysia, aabdullah@iium.edu.my
}

\begin{abstract}
If we consider the state of the world economy, especially in the OIC countries, some countries have to struggle in dealing with the problems of poverty. Hypothetically, the wealth of natural resources is potentially in the welfare of the population, but the facts on the ground say the situation is another in which it is far from being wellbeing. This study aims to analyze poverty in OIC countries by using a development model proposed by Ibn Khaldun. The model consists of six variables: human resource variable (proxy HDI), the variable role of government (proxy government spending in education and health), variable of development (proxy foreign direct investment), state assets variable (proxy for GDP/capita), justice variable (gini index proxy) and sharia variable (a proxy perception index of corruption). This study uses panel data regression analysis with nine object OIC member countries (Indonesia, Malaysia, Egypt, Azerbaijan, Kazakhstan, Tajikistan, Kyrgyzstan, Turkey and Benin) over the years from 2010 to 2016. The results showed that the variables of development model Ibn Khaldun significant effect on poverty in OIC countries is development variable, the variable role of government (proxy for government spending in health sector), justice variable, wealth nation variable and control variables (unemployment). While the role of government variable (proxy government spending in the education sector), HR variables and sharia variables not significant. From these studies, it can be concluded that not all the variables of development model Ibn Khaldun significant effect on poverty in OIC countries.
\end{abstract}

Keywords: Poverty, Development, OIC and Ibn Khaldun.

JEL Classification: B3; E0; I3; N0.

Article history:

Received : : October 27, 2018

Revised : April 10, 2019

Accepted : May 29, 2019

Available online : July 30, 2019

https://doi.org/10.21098/jimf.v5i2.1066 


\section{INTRODUCTION}

As a religion whose goals are to spread grace for the whole of universe, Islam gives attention to poverty alleviation because poverty is considered as the trigger of various forms of evil. Therefore, poverty becomes a problem to be solved with the concept of development that is pro poor growth. Development is considered successful when viewed from the benchmarks of economic growth, economic structure and the smaller income gap among population, regions and sectors. The main objectives of economic development efforts besides creating the highest growth should also eliminate or reduce poverty levels, income gaps and unemployment rates (Todaro, 2006). Therefore, the priority in development is to eliminate poverty. Poverty is a complex issue, because it is not only related to the low level of income and consumption but also related to the low level of education, health and powerlessness to participate in development and various issues related to human development. Poverty reduction has long been the development agenda and priority in every country. Direct and indirect policies, strategies and activities of poverty alleviation have been implemented both nationally and internationally.

Muslim countries with a wealth of natural resources have the potential to prosper the population. However, the fact is different where many Muslim countries are far from prosperity. This is due to the unequal distribution of state wealth. Therefore, the problem of poverty does not escape the government's efforts to overcome it.

Problem of poverty always gets the main attention in the world, especially for countries that are predominantly Muslim. This happened because of the government's awareness that failure to overcome the problem of poverty would lead to the emergence of various social, economic and political problems in the midst of society. In terms of human resources where the concept of human development is related to how to expand human choice (enlarging choice), especially to meet basic needs such as health, education and purchasing power. On the basis of this opposite relationship, a country with good human development quality ideally has a low percentage of poor people (Kumalasari, 2011).

Ibn Khaldun argued that poverty is caused by a process of community decline triggered by illegitimate politics due to the absence of democratic principles that lead to various evils. Poverty is not only caused only by the economic dimension but also influenced by non-economic factors such as moral, intellectual, social, demographic and political so that the solution to alleviate it is not only in the economic field but also in the balance in other sectors (Ibnu Khaldun in Chapra, 2001).

Looking at the state of the world economy, especially in OIC countries, there are still many countries that have to struggle with poverty. This can be seen from the high percentage of poor people in OIC countries as shown in Figure1 below: 
Figure 1.

\section{Graph of Poverty Rate of OIC Countries}

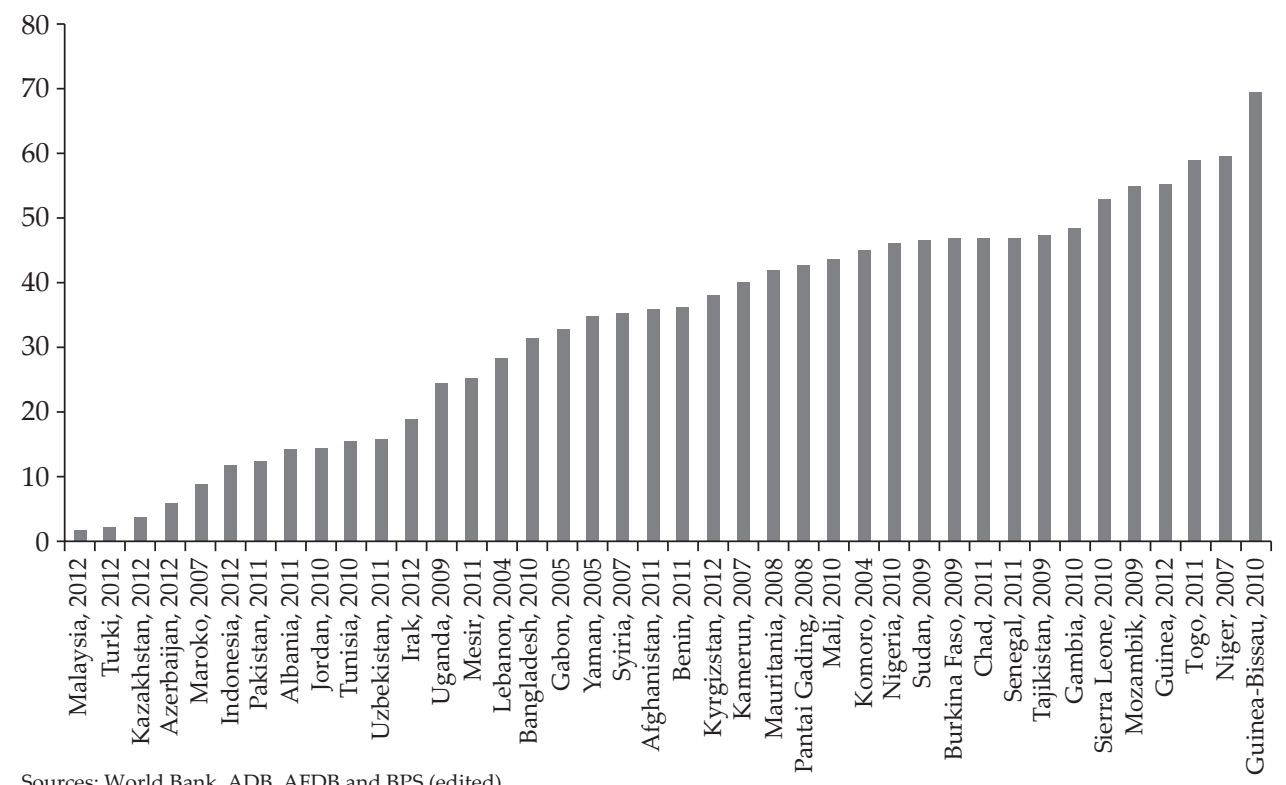

Sources: World Bank, ADB, AFDB and BPS (edited)

Referring to Figure 1, countries with the lowest poverty rates below $10 \%$ are occupied by Malaysia, Turkey, Kazakhstan, Azerbaijan and Morocco. On the other hand, countries with poverty rates between 10\%-30\% are occupied by Indonesia, Pakistan, Albania, Jordan, Tunisia, Uzbekistan, Iraq, Uganda, Egypt and Lebanon. Whereas those above 30\% are occupied by Bangladesh, Gabon, Yemen, Syria, Afghanistan, Benin, Kyrgyzstan, Cameroon, Mauritania, Ivory Coast, Mali, Comoros, Nigeria, Sudan, Burkina Faso, Chad, Senegal, Tajikistan, Gambia, Sierra Leone, Mozambique, Guinea, Togo, Niger and Guinea Bissau. Based on figure 1 it can be concluded that there are still many countries that must make maximum efforts to be able to reduce poverty in their country, especially for countries with poverty rates above 30 percent.

In addition, poverty can also be detected by looking at the gini ratio that illustrates the income inequality between the rich and the poor in a country whose values are between 0 and 1 . The division of the categories is as follows: below 0.3 means evenly distributed in the 1.2 countries in this category are Kazakhstan and Afghanistan. The Gini index value between 0.3 to 0.4 means that evenness is in the 1.2 image of countries in this category, namely: Pakistan, Tajikistan, Iraq, Azerbaijan, Egypt, Bangladesh, Mali, Kyrgyzstan, Albania, Niger, Sudan, Sierra Leone, Jordan, Syria, Tunisia, Uzbekistan, Maldives, Yemen, Benin, Iran, Cameroon, Togo, Guinea, Chad and Burkina Faso. The Gini index value between 0.4 and 0.5 means that it is relatively lame in the figure 2 of countries in this category, namely Turkey, Senegal, Mauritania, Morocco, Indonesia, Qatar, Gabon, Ivory Coast, Malaysia, Uganda, Mozambique, Gambia and Nigeria. While the index value is above 0.5 , it means that the inequality is very bad in the figure 2 countries in this category are only Comoros. 
Figure 2.

\section{Graph of gini ratio index in OIC}

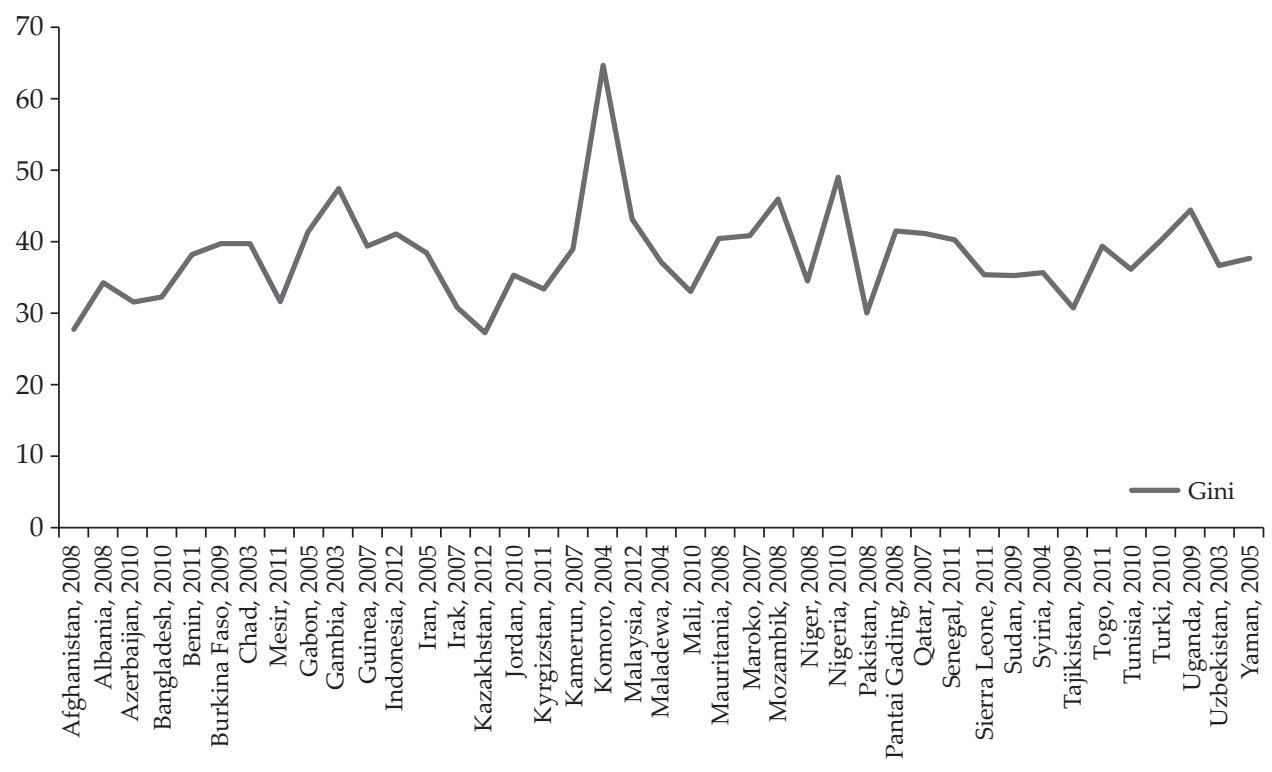

Sources: World Bank, ADB, AFDB and BPS (edited)

Ibn Khaldun argues that poverty is caused by a process of societal decline triggered by politics that is not valid due to the lack of democratic principles that lead to the emergence of various badness. Poverty is not only caused by economic dimensions but also influenced by non-economic factors such as moral, intellectual, social, demographic and political. As a result, the solution of alleviation is not only in the economic field but also the balance in other sectors (Ibn Khaldun in Chapra, 2001). Concluding the explanation of Ibn Khaldun namely poverty is a classic problem that has existed since the first until now that the solution does require a development that is oriented justice. Therefore, aspects of human resources, justice, development, sharia, the role of government and the wealth of the state are related in the development of a country.

Based on the background, the study analysis of poverty in OIC countries by using the development model study of Ibn Khaldun. The author's interest in the theme of this study is due to the fact that the OIC that is in fact the majority of the population is Muslim and supported by rich natural resources should be able to overcome poverty. On the other hand, the reason the writer uses Ibn Khaldun's development model is because in this model can explain more comprehensively in every dimension of life, namely from the aspect of the role of government, development, state wealth, human resources, justice and sharia. Whereas in modern development economics no one has included sharia aspects, so the writer chooses Ibn Khaldun as the basis of his study based on previous research. Therefore, using the development study, Ibnu Khaldun is expected to explain the factors that affect poverty as a whole, which will later be used in solving poverty problems in OIC countries. 


\section{LITERATURE REVIEW}

\subsection{The Definition and Concept of Poverty}

The Central Bureau of Statistics (BPS) defines poverty as a population with average monthly per capita expenditure below the poverty line. The Poverty Line is the sum of the Food Poverty Line (FPL) and the Non-Food Poverty Line. The Food Poverty Line (FPL) is the total value of expenditures from 52 basic food commodities real consumed by the population, a reference that is then synchronized with 2100 kilocalories per capita per day. The Non Food Poverty Line (NFPL) is the sum of the minimum needs of selected non-food commodities that includes housing, clothing, education and health.

The World Bank defines poverty as a form of deprivation in the welfare of many dimensions. This includes low income and inability to get the basic goods and services necessary to survive with dignity. Poverty also includes low levels of health and education, poor access to clean water and sanitation, inadequate physical security, lack of sound and adequate capacity and opportunities for a better life (Kumalasari, 2011).

Neo-liberal theory defines poverty as an individual problem caused by individual either weaknesses or choices. Poverty will disappear by itself if market forces are needed as much as possible and economic growth is pushed as high as possible. Directly, poverty reduction strategies must be temporary "residual" and only involve families, self-help groups or religious institutions. The role of the state is only as a new "night watchman" can interfere when the institutions are no longer able to perform their duties.

Social-democratic theory defines poverty is not caused by an individual problem, but a structural problem. So, poverty is caused by the injustice and imbalance in society due to the clogging of certain groups' access to various social sources. This theory pivots on mixed economy and demand-management economies because of the economic depression that occurred in the 1920s and 1930s. According to the social-democratic view, the poverty strategy must be institutional (institutionalized) (Suharto, 2005).

Kuncoro (2000) defines poverty as the inability to meet minimum living standards. Low standards of living standards are also associated with small amounts of income (poverty), poor housing, poor health and health services, low levels of community education resulting in low human resources and unemployment. The level of living standards in a country can be measured from several indicators such as Gross National Product (GNP) per capita, relative national growth, per capita income, national income distribution, poverty level and community welfare level.

Arsyad (1999) defines poverty as a multidimensional problem, meaning that complex human needs are covered in various aspects. The primary aspects of poor are assets, socio-political organizations, knowledge and skills. Secondary aspects of poor social are networks, financial resources and information. These dimensions of poverty are manifested in the form of malnutrition, unhealthy housing water conditions, and poor health care and low levels of education. In addition, the poverty dimensions are interconnected both directly and indirectly. This means progress or setbacks in one aspect can affect progress and setbacks on other aspects. Another aspect of poverty is that the poor are human beings both individually and collectively. 
Gazalba (1985) in Hadid (2008), Based on the original language (Arabic) the word poor is derived from the word sakana which means silence or quiet while the word masakin is a form of plural from poor which according to language is taken from sakana which means to be silent or immobile Physical weakness or a patient attitude and qana'ah. Ibn Khaldun defines poverty as a process of societal decline triggered by politics that is not valid due to the lack of democracy that leads to the emergence of various evils. Poverty is not only caused by economic dimensions but also influenced by factors other than economic, such as moral, intellectual, social, demographic and political. Similarly, the Islamic economic dictionary defines the poor as all weak and powerless people because of sickness, old age or a war, whether they are capable of doing a job or not doing a job but not being able to provide for themselves and their families. Thus, the poor are people who have property but are unable to provide for their own needs without any help. The poor and the needy are entitled to zakat (Suwiknyo, 2009).

Generally, the concept of poverty in Islam is seen as one of the causes of the decline and destruction of a nation. Even Islam views poverty as a threat from Satan. Allah says:

Satan threatens you with poverty and orders you to immorality, while Allah promises you forgiveness from Him and bounty. Moreover, Allah is all-Encompassing and Knowing.

Therefore, Islam as a way of life that is universal and comprehensive is very concerned in overcoming the problem of poverty.

The Islamic scholars have different opinions about the notion of the poor and the poor, the strongest opinion in this case is, the fakir is the one who needs help but he does not want to beg while the poor are the ones who need help and beg for others. Meanwhile, according to the consensus of Islamic scholars, fakir are people who have nothing or only have less than half their own needs and dependents, while the poor are those who have half their needs or more, but not sufficient (Qardhawi, 1995). From the sense of the two terms, it appears that the criteria of the indigent have actually included the poor criteria. That's why in the next discussion, the two terms are put together into one term that is poor, like people who do not have enough wealth to meet the basic needs of food, clothing and boards. Allad says in surah 2 verse 268 and surah 65 verse 6 as follows.

Upon the father is the mothers' provision and their clothing according to what is acceptable.

Lodge them [in a section] of where you dwell out of your means and do not harm them in order to oppress them.

As primary needs, these three things, must be fulfilled in its entirety. If one is not fulfilled then someone is categorized as poor. Such is the benchmark of poverty according to Islam. From this it appears how Islam provides assurance to humans to live properly as human beings. This poverty measure applies to all humans, whenever and wherever they are. 


\subsection{The Measurement of Poverty}

BPS has used the same approach in measuring poverty using the basic needs approach from the beginning to the present. The basic needs approach uses Head Count Index (HCI) indicators, namely the number and percentage of poor people below the Poverty Line. Poverty Line is calculated on the basis of the average food and non-food per-capita expenditure in the established reference group. This reference group is defined as the marginal class population, such as those whose lives are categorized are slightly above the initial estimate of the. The initial estimate of this Poverty is calculated based on the previous period inflated/deflate with inflation/deflation. The GK is divided into two parts of the Food Poverty Line and the Non-Food Poverty Line.

The food adequacy limit is calculated based on the amount of rupiah spent on food that meets the minimum energy requirement of 2100 kilocalories per day per day. This benchmark refers to the results of the Food and Nutrition Widyakarya 1978. Since 1993 the calculation of caloric adequacy is based on 52 selected food commodities that have been adapted to the consumption patterns of the population. Meanwhile the non-food adequacy limit is calculated from the amount of rupiah spent on non-food items that meet minimum requirements such as housing, clothing, health, transportation and others. Selection of goods and services non-food experience of development and improvement from year to year adjusted to changes in consumption patterns of the population. In the period before 1993 consisted of 14 commodities in urban areas And 12 rural commodities. Meanwhile, since 1996 consists of 27 sub-groups (51 kinds of commodities) in urban and 25 sub-groups (47 kinds of commodities) in the countryside. The calculation of the number and percentage of the poor population of the province is differentiated by urban and rural areas based on Poverty line, which is also differentiated, by urban and rural (Hajiji, 2010).

World Bank poverty has two criteria: (US \$ 1.25 per capita per day) is a measure of absolute poverty. (US \$ 2 per capita per day) when using the second measure. The US \$ used is US \$ PPP (purchasing power parity) not the official exchange rate (exchange rate).

\subsection{The Types of Poverty}

There are several forms of poverty and the following will be presented various forms of poverty and its understanding.

1. Relative Poverty

Poverty is a relatively poor condition that occurs because of the influence of development policies that have not been able to reach all levels of society, resulting in inequality income distribution. The size used by the World Bank, if the poorest $40 \%$ of the population earns less than $12 \%$ of GDP is a bad imbalance, between $12 \%$ to $17 \%$ are moderate inequality, between $17 \%$ and $22 \%$ are relatively even and above $22 \%$ is evenly distributed. In addition, it can also be the ratio of income gini whose value is between 0 and 1, where if equal or below 0.3 means uniformly, between 0.3 to 0.4 means moderate fairness, 0.4 to 0.5 means relative lame and above 0.5 means very bad imbalance (Damanhuri, 2010). 
2. Absolute Poverty

Poverty in absolute terms is a poor condition determined on the basis of inability to meet minimum basic needs such as food, clothing, health, housing and education needed to live and work. Therefore, the measure is to calculate the number of poor people who are below the poverty line (poverty line). In Indonesia, the size used by the Central Bureau of Statistics is equal to or below 2100 kilocalories. In practice, the absolute poverty line owned by rich countries is higher than the poor countries. This has been expressed by Ravallion, 1998 in Damanhuri, 2010 who explains why, for example, the official figure in the early 1990 s was close to $15 \%$ in the United States and also close to $15 \%$ in Indonesia (much more poor). This means that many of those categorized as poor in the United States are not necessarily poor by Indonesian standards.

3. Structural Poverty

Poverty is structurally poor due to unfavorable structural conditions or life arrangements (Wignjosoebroto, 1995 in Damanhuri, 2010). One example is poverty because the location of the isolated residence is far from the reach of the outside world because of access to the country is difficult or live in areas with critical land that is if the rainy season flooded, while if the dry season experiencing severe drought. In addition, the situation is more severe due to inhibiting structures such as Micro Small Medium Enterprises (SMEs) that difficult access to capital banking, so that remain poor even worsened because of decreasing purchasing power due to inflation, while the business did not develop due to capital difficulties. In addition, farmers and agriculture are sacrificed by industrialization policies that sacrifice their lands, Government Budget, spatial, banking and so on allocate more allocation to the development of manufacturing industries.

4. Cultural Poverty

Culturally poverty is a poor condition caused by customary and cultural factors of a particular region that imprison a person or a community (Damanhuri, 2010). For example, lazy attitude, low work ethic, consumptive, not ready to compete, attitude to grab and take the easy way if necessary to break the law / corruption and so on.

\subsection{Determinants of Poverty}

The World Bank identifies the causes of poverty from the perspective of individual access to a number of key life-sustaining assets, i.e. basic life assets (e.g. health and skills / knowledge), natural assets (e.g. farmland or processed land), physical assets (e.g. capital, production and infrastructure), financial assets (e.g. bank loans and other loans) and social assets (e.g. social security and political rights). The absence of access to one or more of the assets is the cause of a person falling into poverty.

According to Nasikum and Sumiyati (2005) there are processes that determined poverty:

1. Policy induces processes, which are a process of poverty that is preserved and reproduced through the implementation of a policy, among which are antipoverty policies, but the reality precisely preserves. 
2. Socio-economic dualism, the former colony country experiencing poverty due to colonial production patterns, such as farmers become marginal because the most fertile land dominated by large-scale farmers and export-oriented.

3. Population growth, Malthus theory-based perspective, that the increases in population as a series of measurements while the addition of food such as arithmetic.

4. Resources management and the environment, is an element of mismanagement of natural resources and the environment, such as agricultural management that cutting productivity will reduce productivity.

5. Natural cycles and processes, poverty occurs because of natural cycles. For example, living on a critical land, where the land if it rains cause flooding whereas if the dry season will cause water shortage, so as not to allow maximum productivity and continuous.

6. The marginalization of woman, the marginalization of women because it is still regarded as a second class, so that access and rewards of the work are lower than men.

7. Cultural and ethnic factors, the workings of cultural and ethnic factors that maintain poverty. For example, the consumptive pattern on farmers and fishermen during the harvest, as well as customs that are consumptive during traditional or religious ceremonies.

8. Exploitive intermediation, the existence of a helper who becomes a mugger, like loan sharks.

9. Internal political fragmentation and civil strife, a policy applied to an area where strong political fragmentation can be a cause of poverty.

10. International processes, the workings of the international system (colonialism and capitalism) make many countries impoverished.

\subsection{Development Model of Ibnu Khaldun}

According to Ibn Khaldun human is the center of civilization where he views the fall of his building a dynasty or civilization is dependent on the welfare or hardship of human life. In his analysis, the phenomenon of the rise of a civilization depends not only on economic variables, but also on a number of other factors that contribute to the quality of individuals, society, authorities and institutions. Therefore Muqaddimah's book tries to determine the factors that influence its quality by analyzing related factors such as the role of moral, psychological, political, economic, social, demographic and historical factors (Chapra, 2001). The characteristics of Ibn Khaldun's model of development is summarized in the overall model summarized in his counsel to kings as follows:

"The power of sovereignty (al-mulk) cannot be maintained unless by implementing sharia, sharia cannot be implemented except by a sovereignty (al-mulk), sovereignty will not gain strength unless supported by human resources (arrijal), Can be maintained except with property (al-mal), property cannot be obtained except by development (al-imarah), development cannot be achieved except with justice (aladl), justice is the yardstick (al-mizan) God to evaluate man and sovereignty has a responsibility to uphold justice." 
This counsel, in Ibn Khaldun's own words, consists of eight principles of political wisdom, each associated with the other to gain strength in a cycle where the beginning and the end are indistinguishable.

By considering the development model, the authors analyze that because in the study Muqaddimah focus on human beings so prosperous in this case is not classified as poor it can be concluded that to overcome poverty is not only limited to the economic dimension alone but also influenced by factors other than the economy, Moral, intellectual, social, demographic and political. Therefore the appropriate solution to reduce poverty not only focuses on one economic sector, but also in all sectors is summarized as follows: $P=f(W, G, N, S$, g and $j)$

Poverty $(\mathrm{P})$ is a function of state assets $(\mathrm{W})$, government roles $(\mathrm{G})$, Human Resources (N), sharia (S), development (g) and justice (j) (Suyanto, 2004). The reason the authors take the statement as the basis for thinking because in general in development which became one of the indicators of success that is to overcome poverty.

To better understand the statement then described each model of Ibn Khaldun development model that is, as follows:

1. The Role of Human-being

According to Ibn Khaldun man is the center of development of a country, because the advancement and retreat of a civilization and government is closely related to the welfare or misery of man or society within the country concerned. Where it all depends not only on the economic dimension, but there are other factors that influence the quality of individuals, communities, authorities and institutions through a process of causation over a long period. It cannot be separated from the purpose of development to achieve welfare when welfare has been achieved, then people will be able to work effectively, creatively and optimally so it can be concluded that the influence of human resources to poverty is negative, when the quality of human resources increases it will decrease poverty.

2. The Role of Justice in a country

In this case, the state serves to help the people in running their business to be more efficient and prevent them from dangerous and illegal aspects of doing business. Thus, the concept of state initiated by Ibn Khaldun is not a laissez faire or totalitarian state. It is a state that guarantees the validity of sharia and serves as an instrument of human development and prosperity (Khaldun in Chapra, 2001).

3. The Role of Sharīah

Sharia is capable of fulfilling public interests, encouraging cooperation and reducing differences and has proven to be the strongest adhesive in defending large groups. Another surplus of sharia is to help humans to instill socially desirable traits.

4. The Role of Nation Wealthy

The greater the income will contribute more to development and wealth. In other words, wealth will increasingly provide a high level of usefulness if it is rotated or used to invest, when compared to store alone. 
5. The Role of Development

An increase in income will contribute to the increase and acceptance of taxes and allow the government to spend more on the welfare of the people. This will lead to an expansion in economic opportunities and greater development which in turn will encourage the natural growth of the population as well as the migration of skilled and unskilled labor and educated people elsewhere, further strengthening the intellectual capital and human resources of the community.

\subsection{Previous Studies}

Some studies about poverty become the fundamental idea of this research. In 2013, Smida conducted a research regarding to Interaction between Poverty, Growth and Inequality during the Crisis: A Panel Data Study. The study included MENA samples consisting of eight countries (Algeria, Egypt, Iran, Jordan, Morocco, Tunisia, Syria and Yemen) from 1990 to 2009. From the results of this study found that economic growth in a country is necessary, but not quite effective in reducing poverty. Inequality indicators allow for a worsening situation of poverty so that real action is needed to minimize it in order to reduce poverty. For control variables such as: trade openness, infrastructure indicators, positively affects poverty, whereas demographic growth and education spending negatively affect various indicators of poverty. However, for the variable inflation and exchange rate impact is still ambiguous.

In same year, Affandi and Astuti carried out study about Dynamic Model of Ibn Khaldun Theory on Poverty (Empirical Analysis on the Poverty in Majority and Minority Muslim Population after the Financial Crisis). His study analyzes the factors affecting poverty in Indonesia, Malaysia and Pakistan representing countries with Muslimmajority populations and India as a country with a Muslim minority population. This study uses secondary data from 2000-2010 or after the financial crisis of 1997. The results show that dynamic model variables Khaldun (HDI, GDP, gini ratio, investment, health, education and CPI) significantly affects poverty levels in Indonesia as a country with a majority Muslim population, whereas in Pakistan only the HDI variable has significant influence. Meanwhile in Malaysia and India the dynamic model of Ibnu Khaldun did not significantly affect poverty levels.

Ashalou in 2012 did a research about Socioeconomic Determinants of Poverty among Urban Households in South-West Nigeria. The purpose of this study was to examine the poverty situation among urban households in the Ekiti region of Nigeria. Therefore, the research area is emphasized on how socio-economic characteristics of households and how they affect poverty. This study used primary data by selecting 80 households interviewed using a structured questionnaire. The findings of this study found that 41 percent of households covered in this study were poor and had to mobilize financial resources up to 45 percent from 1 US Dollar per day (for each household member) to get out of poverty. The dependency ratio, household assets and educational status of the head of household are the socioeconomic factors affecting poverty.

Xin utilized Regression Logit and Tobit to measure the poverty in China. This study uses the Ravallion poverty line using survey data from rural households 
in two Chinese provinces, Hubei and Inner Mongolia. The results show that the official poverty line in China does not substantially reflect the true situation of rural poverty. In addition, most of the variables show a significant effect on rural poverty under different poverty lines. With regard to the location of areas in isolated areas, mountains, lack of adequate irrigation, size of family members, lack of access to capital, making a living exclusively in the agricultural sector will make rural households more vulnerable to becoming poor. Rural households with school dropout members or minimal skill and work experience affect the rural poverty level in China.

Martin Ravallion (2009) conducted a research by using Multi linear regression. In this paper, author examined three possible factors determining the components of poverty distribution reduction, namely: changes in sectorial growth patterns, heterogeneity that explain spatial variations in elasticity and contemporary changes in macroeconomic and redistributive policies. Author found a marked difference in the poverty reduction effects of growth across sectors, with growth in the service sector consistently more pro-poverty than agriculture or industry. In addition, author also found evidence of spatial variation in growth elasticity where the effects of poverty alleviation from growth in certain industrial sectors vary widely across states. In addition, investment in human capital will contribute to reduce poverty. However, it is the biggest source of poverty reduction due to changes in government policy in the area of macroeconomic stabilization and income redistribution.

\section{METHODOLOGY}

\subsection{Data}

The type of data in this study is secondary data that it is monthly time-series data for the period 2010-2016 and cross-section data. The range of data is taken from 2010 where the global economy is getting better after global crisis in 2008 (UN, 2010). In addition, it is only until 2016 to avoid the recession risk assumptions in 2018 (Borio, Mathias, \& Xia, 2018).

The Data covers nine samples of OIC member countries namely Indonesia, Turkey, Azerbaijan, Kazakhstan, Kyrgyzstan, Tajikistan, Benin, Egypt and Malaysia. In general, the data in this study were obtained from the World Bank, the United Nations Development Program (UNDP), Transparency International, the Asian Development Bank (ADB), the African Development Bank (AFDB), the Central Bureau of Statistics (BPS) and OIC.

\subsection{Model Development}

In accordance with the formulation of the problem how to generate the model of dynamics of Ibn Khaldun's influence on poverty in majority and minority of Muslim population, then the proposed dynamics of Ibn Khalduns model is as follows:

$$
\mathrm{P}=f(\mathrm{~W}, \mathrm{G}, \mathrm{N}, \mathrm{S}, \mathrm{g} \text { and } \mathrm{j})
$$


where:
$\mathrm{P} \quad=$ Poverty.
$\mathrm{W} \quad=$ Wealth of the country.
$\mathrm{G} \quad=$ Government.
$\mathrm{N}=$ Human resources/people.
$\mathrm{S} \quad=$ Sharia
$\mathrm{g}$ and $\mathrm{j}=$ Development and justice

Variables in equation (1) imply a dynamic model of Ibn Khladun. In this case the variables included in the model of the dynamics of Ibn Khaldun to be formed or manifest variable proxy variable, so the model becomes:

Pov $=f($ inv, hlth, educ, LnIPM, Lncpi, Lngdp, Lngini)

where:

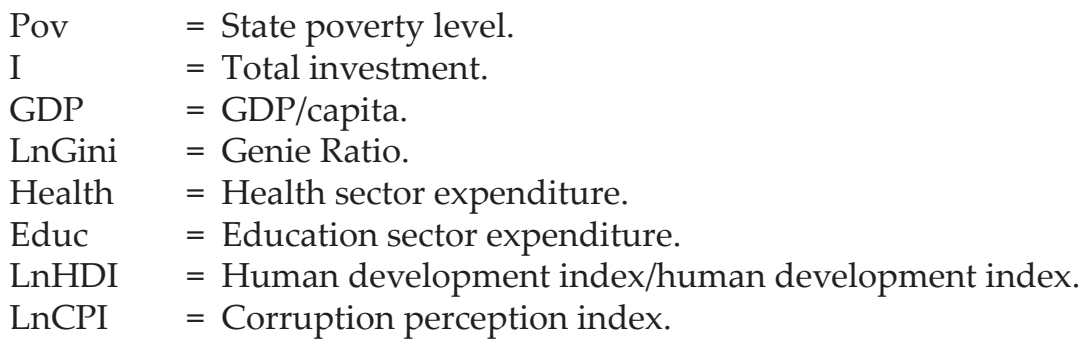

Table 1.

Variable Definition, Measurements, and their Sources

\begin{tabular}{|c|c|c|c|c|}
\hline No. & Variable & Definition & Measurement Unit & Source \\
\hline 1 & Pov & $\begin{array}{l}\text { National poverty line } \\
\text { (\% population) }\end{array}$ & Percentage & $\begin{array}{l}\text { World Bank, ADB, } \\
\text { AFDB }\end{array}$ \\
\hline 2 & Inv & $\begin{array}{l}\text { Direct foreign investment } \\
\text { (\% PDB) }\end{array}$ & Percentage & World Bank \\
\hline 3 & GDP & $\begin{array}{l}\text { GDP/kapita, (based on constant } \\
\text { international price berdasarkan } \\
2005 \$ \text { ) }\end{array}$ & US\$ & World Bank \\
\hline 4 & Gini & Gini ratio & Ratio & $\begin{array}{l}\text { World Bank, ADB, } \\
\text { AFDB, BPS }\end{array}$ \\
\hline 5 & Hlth & $\begin{array}{l}\text { Government expenditure in } \\
\text { health sector (\% PDB) }\end{array}$ & Percentage & World Bank \\
\hline 6 & Educ & $\begin{array}{l}\text { Government expenditure in } \\
\text { education sector (\% PDB) }\end{array}$ & Percentage & World Bank \\
\hline 7 & HDI & Human Development Index & Index & $\begin{array}{l}\text { United Nations } \\
\text { Development } \\
\text { Programme }\end{array}$ \\
\hline 8 & CPI & Corruption Perception Index & Index & $\begin{array}{l}\text { Transparency } \\
\text { International }\end{array}$ \\
\hline 9 & Unp & $\begin{array}{l}\text { Total unemployed (\% total } \\
\text { labor) (variable control) }\end{array}$ & Percentage & World Bank \\
\hline
\end{tabular}




\section{The Relation between Dependent and Independent Variables}

1. Relation of Variable Human Resources to Poverty

According to Ibn Khaldun man is the center of development of a country, because the advancement and retreat of a civilization and government is closely related to the welfare or misery of man or society within the country concerned. From these statements can be concluded that human resources and poverty have a negative relationship, where in general if the condition of human resources in a country good, then it will reduce the level of poverty. The HR variable is approximated by HDI proxy. If the value of HDI is high then it will generally decrease poverty. This is reinforced by the results of previous research that confirms that HDI significantly affects poverty (Setyaningsih, 2012; Affandi \& Astuti, 2013).

2. Relation of Government Role Variable to Poverty

According to Ibn Khaldun, the state in this case that is represented by the government has a very important role in the life of society. Nevertheless, the state should not exercise its absolute power, but must be able to use its power to enable markets to function properly and create an appropriate environment for the realization of development and justice. In this case, the role of government through the state expenditure used in the education and health sector is pivotal. There fore, it can be channeled effectively and efficiently. From these statements can be concluded that there is a negative relationship between the roles of government to poverty, where in general if the state of government in a country through its programs effective and efficient it will reduce the level of poverty. Government role variables are approached with government spending proxies for the health and education sectors. If government spending on the health and education sectors is high then generally will reduce poverty, This is reinforced by previous research results which confirm that government spending on the health and education sectors significantly affects poverty (Setyaningsih, 2012; Affandi \& Astuti, 2013).

3. The Relationship of Justice Variables to Poverty

According to Ibn Khaldun, justice aims to ensure the welfare of society through the fulfillment of their respective obligations and equally enjoy the results of development fairly. The absence of justice tends to lead to disappointment in society, discouraging expectations and adversely affecting community solidarity. From these statements can be concluded that justice and poverty have a positive relationship, where in general if justice in a country has been enforced so that there is no imbalance between the rich and the poor. It will reduce the level of poverty. The justice variable is approximated by the proxy of the genie index. If the index value is high then it will generally increase poverty. This is reinforced by the results of previous research that confirmed that the index of genie significantly affects poverty (Setyaningsih, 2012; Affandi \& Astuti, 2013; Chemli \& Smida, 2013; Agrawal, 2008).

4. The Relationship Between Variable of State Assets and Poverty

According to Ibn Khaldun, the wealth of the state is needed for the welfare of the people. Therefore, he emphasized the role of investment in more depth while saying: "And know wealth will not grow when it is dumped and stored. It will grow and develop when it is spent for the benefit of the welfare of the people, to be given to the rightful and eliminate the difficulties." 
From that statement can be concluded that there is a negative relationship between the wealth of the country and poverty, where in general if a country has sufficient wealth then it will reduce the level of poverty. State wealth variable is approached with proxy of GDP / capita. If GDP / capita is high then in general will reduce poverty, this is reinforced by previous research results which confirm that GDP / capita significantly affects poverty (Affandi and Astuti, 2013).

5. The Relationship of Development Variables with Poverty

According to Ibn Khaldun, an increase in income will contribute to tax revenues and allow the government to spend more for the welfare of people. This will lead to an expansion in the growing economic opportunities for development. With the rapid development and advanced, it will make the community activities well facilitated because adequate access can facilitate the course of economic transactions. From these statements can be concluded that development and poverty has a negative relationship, where in general if development in a country has advanced and rapidly it will reduce the level of poverty. Development variables are approximated by direct foreign investment proxies. If foreign direct investment is high then generally will reduce poverty, this is reinforced by the results of previous research which confirmed that foreign direct investment affects poverty significantly (Setyaningsih, 2012; Affandi \& Astuti, 2013).

6. The Relation of Sharia Variable to Poverty

According to Ibn Khaldun, the application of sharia is needed in helping humans to instill socially desirable traits. Such qualities as diligence, honesty, integrity, austerity and a sense of solidarity that can help development, justice, mutual care, cooperation, peace, harmony, social and prevent socially harmful behavior. Therefore, sharia rules provide general principles that need to revolve following the changing needs of human beings along with changes in space and time in other sense sharia is the rule of God law that is not dynamic static nature. From these statements can be concluded that the relation between sharia to poverty is a negative relationship, where in general if the principles of sharia in a country has been enforced it will reduce the level of poverty. Sharia variables are approximated by the proxy of corruption perception index. If the value of corruption perception index is high then it will generally decrease poverty. This is reinforced by the results of previous research that confirmed that the corruption perception index significantly affects poverty (Affandi and Astuti, 2013).

\subsection{Method}

This study employs regression analysis of panel data (pooled data) as a data processing tool. Analysis by using data panels is a combination of time series data and cross-section data. In the model data panel model equations using crosssection data can be written as follows:

$$
\mathrm{Y}_{\mathrm{i}}=\beta_{0}+\beta_{1} \mathrm{X}_{\mathrm{i}}+\mu_{\mathrm{i}} ; \mathrm{i}=1,2, \ldots, \mathrm{N}
$$

$\mathrm{N}$ : the number of cross section data. 
Models with time series data:

$Y_{t}=\beta_{0}+\beta_{1} X_{t}+\mu_{t} ; t=1,2, \ldots, T$

$\mathrm{T}$ : The number of time series data.

Because the panel data is a combination of cross section data and time series, then the modeling for panel data is:

$\mathrm{Y}_{\mathrm{it}}=\beta_{0}+\beta_{1} \mathrm{X}_{\mathrm{it}}+\mu_{\mathrm{it}}$

$\mathrm{i}=1,2, \ldots, \mathrm{N} ; \mathrm{t}=1,2, \ldots, \mathrm{T}$

where:

N : Number of observations.

Q : Time (period).

N x T : The number of panel data.

Generally, there are three approaches in panel data methods, namely Fixed Effects Model (FEM), Random Effect Model (REM), and Pooled Least Square (PLS). Both are distinguished by the presence or absence of correlations between the error components and the independent variables.

\section{Fixed effects method}

The difficulties in employing ordinary least square is the use of ordinary least square where the use of intercept and slope from regression equation assumed to be constant across the time that might be not realistic. This can be generalized by inserting dummy variable to obtain differences in parameter whether for cross section or time series (Manurung, 2012). The fixed effect method is as follow:

$Y_{i t}=\alpha+\beta X_{i t}+\Upsilon_{2} W_{2 t}+\Upsilon_{3} W_{3 t}+\ldots+\Upsilon N W N_{t}+\delta_{2} Z_{i 2}+\delta_{3} Z_{i 3}+\ldots+\delta T Z i T+\varepsilon_{i t}$

where:

$Y_{\text {it }}=$ dependent variable for the ith individual and the time to $t$.

$X_{i t}=$ independent variable for the ith individual and the time to $t$.

$\mathrm{W}_{\mathrm{it}}=$ and $\mathrm{Z}_{\mathrm{it}}$ dummy variables are defined as follows:

$\mathrm{W}_{\mathrm{it}}=1$; for individual $\mathrm{i}, \mathrm{i}=1,2, \ldots, \mathrm{N}$.

$=0$; other.

$\mathrm{Z}_{\mathrm{it}} \quad=1$; for period $\mathrm{t} ; \mathrm{t}=1,2, \ldots, \mathrm{T}$.

$=0 \quad ;$ other.

\section{Random effects model}

The use of fixed effects model in the panel method will also lead to a consequence (trade off). The use of dummy variables will reduce the number of degree of freedom that in turn will reduce the efficiency of parameter estimation. So that 
the solution that can be used to address this problem in the fixed effects method is to use a random effects model. In this model, the different parameters between regions and between the times will be placed into error and that is why the random effects model is often called the error component model (Gujarati and Porter, 2009). Random effects model in this method are as follows:

$$
\begin{aligned}
& Y_{\mathrm{it}}=\alpha+\mathrm{X}_{\mathrm{it}} \beta_{\mathrm{j}}+\varepsilon_{\mathrm{it}} \\
& \varepsilon_{\mathrm{it}}=u_{\mathrm{it}}+\mathrm{V}_{\mathrm{t}}+\mathrm{w}_{\mathrm{it}}
\end{aligned}
$$

where:

ui, $N\left(0, \delta_{u}{ }^{2}\right)=$ component of cross section error. vt, $N\left(0, \delta_{v}{ }^{2}\right)=$ the component of time series error. wit, $\mathrm{N}\left(0, \delta_{\mathrm{w}}{ }^{2}\right)$ = component of error combinations.

\section{Pooled Least Square (PLS)}

Gujarati and Porter (2009), this approach is to use a combination of all data (pooled), so that there is $\mathrm{N} x \mathrm{~T}$ observation, where $\mathrm{N}$ shows total unit cross section and $\mathrm{T}$ shows the number of time used, which is regressed with the model: where $\alpha_{\mathrm{i}}$ is constant for all observation, or $\alpha_{\mathrm{i}}=\alpha$, formulated as:

$$
\begin{aligned}
\widehat{\alpha} & =\bar{y}-\widehat{\beta} \bar{x} \\
\widehat{\beta} & =\frac{1}{N T} \sum_{i=1}^{N} \sum_{t=1}^{T} \tilde{x}_{i t} \tilde{y}_{i t} \\
& =\frac{1}{N T} \sum_{i=1}^{N} \sum_{t=1}^{T} \tilde{x}_{i t}^{2}
\end{aligned}
$$

By $\bar{x}=(1 / \mathrm{NT}) \cdot \sum_{i=1}^{N} \sum_{t=1}^{T} \tilde{x}_{i t}$ and $\bar{x}_{\mathrm{it}}=x_{\mathrm{it}}-x$ (the same for $\mathrm{y}$ ) by combining or collecting all cross section data and time series data, it can increase the degree of freedom so that it can provide more efficient estimation results, so that:

$$
\begin{aligned}
\operatorname{var}(\beta) & =\operatorname{var}\left(u_{i t}\right) \\
& =\sum_{i=1}^{N} \sum_{t=1}^{T} \tilde{x}_{i t}^{2}
\end{aligned}
$$

\section{RESULT AND ANALYSIS}

\subsection{Result}

Based on table 2, the estimation results of the panel data regression model are presented, which are models used to examine the factors that determine poverty using the basis of the dynamic cross model of Ibn Khaldun. The estimation coefficient presented is the result of four estimation methods, namely PLS, FEM, and REM. The use of various estimation methods is expected to show variations in estimation results, as with goodness, and validity among various estimation methods used. 
In general, the three estimation methods show good results, except the FEM model. This can be seen from the level of significance and the sign of the estimation coefficient generated from the model. In the three estimation methods used, it can be seen that FEM is preferred over two other estimation methods, namely PLS and REM. This is reflected in the Chow test statistic value and the Hausman test statistical value, each of which is significant at 1 percent level. The results of the Chow test indicated that FEM was preferred over PLS while the results of the Hausman test indicated that FEM was preferred over REM.

Table 2.

Econometric Result

\begin{tabular}{|c|c|c|c|}
\hline Coefficient & PLS & FEM & REM \\
\hline \multirow[t]{2}{*}{ Constant } & $128.034^{* * *}$ & $348.228^{* * *}$ & $128.034^{* * *}$ \\
\hline & -0.001 & 0 & 0 \\
\hline \multirow[t]{2}{*}{ Health Expenditureit } & $3.705^{* * *}$ & 3.199 & $3.705^{* * *}$ \\
\hline & 0 & -0.122 & 0 \\
\hline \multirow[t]{2}{*}{ Education Expenditureit } & -0.4203 & -1.172 & -0.42 \\
\hline & -0.617 & -0.22 & -0.616 \\
\hline \multirow[t]{2}{*}{ GDP/Capitait } & $-14.249^{* * *}$ & $-42.350^{* * *}$ & $-14.249^{* * *}$ \\
\hline & 0 & 0 & 0 \\
\hline \multirow[t]{2}{*}{ Gini Indexit } & 6.648 & $11.169^{*}$ & 6.648 \\
\hline & -0.329 & -0.092 & -0.326 \\
\hline \multirow[t]{2}{*}{ Investmentit } & $0.486^{* * *}$ & -0.124 & $0.486^{* * *}$ \\
\hline & -0.004 & -0.446 & -0.003 \\
\hline \multirow[t]{2}{*}{ HDIit } & -4.94 & -1.484 & -4.94 \\
\hline & -0.713 & -0.926 & -0.713 \\
\hline \multirow[t]{2}{*}{ Unemployedit } & $1.001^{* * *}$ & -0.11 & $1.001^{* * *}$ \\
\hline & -0.002 & -0.873 & -0.001 \\
\hline \multirow[t]{2}{*}{ Corruption Perception Indexit } & -3.448 & -2.007 & -3.448 \\
\hline & -0.491 & -0.718 & -0.489 \\
\hline R2 & 0.815 & 0.616 & 0.92 \\
\hline \multirow[t]{2}{*}{ F/Wald Test } & $44.53^{* * *}$ & $14.61^{* * *}$ & $356.24^{* * *}$ \\
\hline & 0 & 0 & 0 \\
\hline Chow-F Test & & & $44.53^{* * *}(0.000)$ \\
\hline Hausman Test & & & $34.04^{* * *}(0.000)$ \\
\hline \multirow[t]{2}{*}{ LM Test } & & & 0 \\
\hline & & & -1 \\
\hline $\begin{array}{l}\text { Modified Wald test for } \\
\text { groupwise heteroskedasticity }\end{array}$ & & & $675.11^{* * *}(0.000)$ \\
\hline $\begin{array}{l}\text { Wooldridge test for } \\
\text { autocorrelation }\end{array}$ & & & $34.864^{* * *}(0.000)$ \\
\hline
\end{tabular}




\subsection{Analysis}

Furthermore, a partial test of each independent variable along with a discussion of the theory and previous research are explained as follows:

\section{Government Expenditure in Health}

Based on Table 2 health expenditure has a significant effect on poverty in the OIC country with a positive relationship. So any increase in the health sector budget by 1 percent will increase poverty by 3.705 percent. Conversely, if every reduction in the health sector's budget by 1 percent will reduce poverty by 3.705 percent (ceteris paribus).

Look at the econometric results; it is contrary to the existing theory. Where according to Todaro and Smith (2006) one of the causes of poverty is poor health facilities and services that are very limited. Therefore, increasing the health budget should reduce poverty.

This opinion is in line with Ibn Khaldun's idea that the role of government in poverty alleviation programs through adequate health budget policies can overcome poverty problems. Government spending on the health sector should have a negative relationship to poverty. Differences in the results of econometrics with existing theories may be caused by budget allocations for health that are not well targeted. So that the greater the amount of the budget that is issued, the more it reduces the other government budgets that can reduce poverty because those that reach the community are only a little due to corruption or other forms of fraud. This is supported by the score of the corruption perception index in nine OIC countries that are still in low categories, which means that the state still has to fix the existing corruption problems. If the allocation of health budgets is appropriate, efficient and evenly distributed, especially for the poor, poverty can be overcome. In addition, government spending in the health sector is small; a large population cannot reach the poor.

So that increasing government spending does not necessarily reduce poverty quickly. As with the large health budget with a small population, it can reach the whole community, especially for the poor. Besides that, the main factor that must be considered is the awareness of the importance of maintaining health by applying a healthy lifestyle. Because it will be a waste of work if the maximum effort made by the government is not balanced with the level of public awareness. The results of the authors' research are also supported by research (Setyaningsih, 2012). Where in Muslim countries government spending in the health sector has a significant positive relationship to poverty levels.

\section{Government Expenditure in Education}

Based on the econometric table 2, education expenditure has no significant effect on poverty in OIC countries. Look at the results of the econometrics; this contrasts with the theory that government spending in the education sector should have a significant effect on poverty. Because according to Todaro and Smith (2006) one of the causes of poverty is that educational facilities in several developing countries and the existing curriculum contents are relatively less relevant and inadequate.

The theory clearly stated that the government's efforts in alleviating poverty, especially through an adequate education budget, are a good formula in 
overcoming poverty. But sometimes the cost of education is expensive, making the poor unable to get a tertiary education that ultimately affects the low level of employment with a low salary and does not even have a job. Therefore, equitable education for the people, especially providing education funding for the poor is very important.

This is in line with Ibn Khaldun's idea that the role of the government in ensuring education for its people is very important because it can overcome poverty itself this in line with Affandi and Astuti (2014). However, differences in the results of econometrics with existing theories may be due to the increase in the education budget should be supported by the provision of suitable jobs so as to reduce unemployment and ultimately reduce poverty.

Although contrary to theory, it turns out that research by Setyaningsih (2012) also states the same thing where the government budget for the education sector does not have a significant influence in both Muslim and non-Muslim countries. Moreover, research by Affandi and Astuti (2013) also has the same results where Pakistan, Malaysia and India education budget variables have no significant effect on poverty levels.

\section{GDP per Capita}

Based on the econometric table 2, GDP per capita has a significant effect on poverty in the OIC country with a negative relationship. Therefore, every increase in per capita income of US \$ 1 will reduce poverty by 14.294 percent. Conversely, if every decrease in per capita income of US \$ 1 will increase poverty by 14.294 percent (ceteris paribus).

Look at the econometric results in accordance with existing theories because according to Kuncoro (2000) poverty is caused by the problem of low per capita income. Therefore, high per capita income can overcome poverty because people's needs are met properly.

The theory is in line with Ibn Khaldun's thinking where the role of state wealth is needed because it can be beneficial for the people; this is reflected in the high per capita income. Besides this statement is also supported by the results of research from (Guiga and Rejeb, 2012; Setyaningsih, 2012; Affandi and Astuti, 2013) which confirms that per capita income has a significant effect on poverty with a negative relationship.

\section{Gini Ratio}

Based on the econometric table 4.1, the Gini ratio has a significant effect on poverty in the OIC country with a positive relationship. Therefore, every increase in this index of 1 value will increase poverty by 11.169 percent. Conversely, if every decrease in the index is 1 value, it will reduce poverty by 11.169 percent (ceteris paribus).

Look at the econometric results in accordance with existing theories because according to Todaro and Smith (2006) poverty is caused by one of them by a very unequal or unequal income distribution. Therefore, a fair income distribution can prevent poverty because economic results are not only enjoyed by rich people but can be enjoyed by all levels of society. 
The theory is in accordance with Ibn Khaldun's opinion that explains the importance of the role of justice in a country. In addition, this statement is also supported by the results of research from (Guiga and Rejeb, 2012; Affandi and Astuti, 2013; Chemli and Smida, 2013; Affandi and Astuti, 2014) which emphasize that this index has a significant effect on poverty with a positive relationship.

\section{Foreign Investment}

Based on the econometric table 2 foreign investment has a significant effect on poverty in the OIC country with a positive relationship. Therefore, every increase in investment of 1 percent will increase poverty by 0.486 percent. Conversely, if every decrease of investment by 1 percent will reduce poverty by 0.486 percent (ceteris paribus).

Look at the econometric results; it is contrary to the existing theory. Where according to the World Bank (World Bank) one of the causes of poverty from the perspective of the lack of individual access to physical assets (e.g. capital, production facilities and infrastructure).

The theory is in accordance with Ibn Khaldun's opinion that explains that development capital will increasingly provide a high level of benefit if it is played or used to invest, when compared to store. Given the importance of investment in alleviating poverty, investment should have a negative effect on poverty.

The difference between the results of econometrics and existing theories may be due to using variables with a direct foreign investment approach, so that the greater the foreign direct investment entering the OIC, the less benefits the community can get, in other words, the investment benefits are only felt by foreign parties. The greater the value of foreign direct investment, the more it increases poverty in the OIC countries. Thus, between investment and poverty should have a negative relationship as the result of study by Affandi and Astuti (2014).

\section{Human Development Index}

Based on the econometric table 2, HDI has no significant effect on poverty in OIC countries. The econometric results are not in accordance with the existing theory. Where According to Chiller (2004) in Bellinger (2007), mentioning one of the things that causes poverty is the lack of motivation or skills both of these things will of course affect HR.

If motivation and skills are less then it will cause HR to be less competent. Ibn Khaldun also confirmed that humans are the center of the development of a country, because the advancement and retreat of a civilization and government are closely related to the welfare or misery of people or society in the country concerned.

The difference between the results of econometrics and the existing theories may be due to the HDI indicators measured from the three main indicators that are still not enough in representing human development. Chapra, 2008 explained that there are still other indicators that are equally important in supporting HDI including justice, family, job security, harmonious society and environmental security as well as many other aspects that can represent so that the HDI is more comprehensive. 
Nevertheless, the results of the author's research are also supported by research (Affandi and Astuti, 2013). Where in Malaysia and India the dynamic model variable of Ibn Khaldun does not significantly affect poverty.

\section{Corruption Perception Index}

Based on the econometric table 2 CPI has no significant effect on poverty in OIC countries. The econometric results are not in accordance to the existing theory. Because according to Ibn Khaldun the absence of sharia will lead to inequality, imbalances and disappointments which in turn will cause economic decline and disintegration of society so that it will ultimately affect poverty itself.

The differences in the results of econometrics and existing theories may be due to the GPA proxy being considered far in representing the sharia approach. In addition, the CPI approach cannot be seen as an indicator of the assessment of corrupt countries or not because it does not measure the efforts that have been made to eradicate corruption. The index should be juxtaposed with other surveys related to corruption to make it look more intact. The use of respondents who are only limited among experts and business people can cause the resulting assessment to be biased.

Nevertheless, the results of the author's research are also supported by research (Affandi and Astuti, 2013). Where in Pakistan, Malaysia and India, Ibn Khaldun's dynamic model variable does not significantly affect poverty levels.

\section{Unemployment}

Unemployment control variables based on econometric tables 2 unemployed has a significant effect on poverty in OIC countries with a positive relationship. Therefore, every increase in unemployment by 1 percent will increase poverty by 1,001 percent. Conversely, if every decrease in the number of unemployed by 1 percent it will reduce poverty by 1,001 percent (ceteris paribus).

This result is in accordance with the opinion of Sukirno (2004), which states that the adverse effects of unemployment are reducing people's income and this reduces the level of prosperity they achieve. Therefore, the number of unemployed must be suppressed because from there poverty begins. If unemployment can be overcome by creating wide employment, poverty can be overcome.

This statement is also supported by the results of research from (Prastyo, 2010; Purnamasari, 2013; Hakim, 2013) which confirms that unemployment has a significant effect on poverty with a positive relationship.

\subsection{Policy Implications}

Based on the analysis, there are some inputs that can be delivered to policy makers in overcoming the poverty. The government should pay more attention to equitable development where income distribution is evenly distributed with a high GDP per capita level, so that, future-oriented development can be implemented on equitable distribution of income and equal distribution of economic outcomes to all segments of society. Furthermore, increasing economic growth in each country by relying on their potentials and solving the problem of unemployment by facilitating business establishment permits to create job opportunities that its is 
able to absorb a lot of labor. In brief, to be expected that poverty rates in the OIC countries can be reduced.

\section{CONCLUSION AND RECOMMENDATION}

\subsection{Conclusion}

Based on the analysis and discussion that has been done in the previous chapter, it can be concluded that simultaneously the development model of Ibn Khaldun has a significant effect on poverty in OIC countries. However, if partially analyzed Ibn Khaldun's development model variables that have a significant effect on poverty in OIC countries are only development variables, government role variables (proxy for government spending in the health sector), justice variables, state wealth variables and control variables (unemployment). While the role of government variables (proxy for government expenditure in the education sector), HR and sharia variables have no significant effect. From this research, it can be underlined that partially not all variables of Ibn Khaldun's development model have a significant effect on poverty in OIC countries.

\subsection{Recommendation}

The author's recommendations based on this research are as follows:

a. The government should take more step in advancing its role in alleviating the poverty whether direct (education, health, and job opportunities) or indirect (reducing the corruption and foreign investment) action.

b. In using the proxy of sharia variables, no one can directly represent the sharia factor itself, thus need to fit the proxy in the future. In addition, the number of objects should be added where actually the number of OIC countries is 57 countries.

c. In further research, it should discuss more comprehensively related to Ibn Khaldun's development model by using a closer proxy variable

\section{REFERENCES}

Affandi, Akhmad., \& Astuti, Dewi Puji. (2013). Dynamic Model of Ibnu Khaldun Theory on Poverty (Empirical Analysis on the Poverty in Majority and Minority Muslim Population After the Financial Crisis). Humanomics,29(2),136-160

Akerele, D., M. S., Adewuyi, S. A., Phillip, B. B., \& Ashaolu, O. (2013). Socioeconomic Determinants of Poverty Among Urban Households in South-West Nigeria. International Journal of Social Economics, 39 (3),168-181

Agrawal, Pradeep. (2008). Economic Growth and Poverty Reduction: Evidence from Kazakhstan. Asian Development Review, 24 ( 2), 90-115.

Arsyad, Lincolin. (1999). Ekonomi Pembangunan. Yogyakarta: STIE YKPN.

Bellinger, WK. (2007). The economic analysis of public policy. London: Routledge.

Borio, C., Drehmann, M., \& Xia, D. (2018). The Financial Cycle and Recession Risk. BIS Quarterly Review,59-71

Chapra, M.U. (2001). The Future of Economics: An Islamic Perspective. The Islamic Foundation: Markfiled Conference Centre 
Chemli, L., \& Smida, M. (2013). Interaction between Poverty, Growth and Inequality During the Crisis. International Journal of Economics and Finance, 5 (5), 120-130

Damanhuri, D. S. (2010). Ekonomi Politik dan Pembangunan (Teori, Kritik dan Solusi Bagi Indonesia dan Negara Sedang Berkembang). Bogor: IPB Press

Ferreira, L., \& Ravallion. (2009). Poverty Reduction without Economic Growth? (Explaining Brazil's Poverty Dynamics, 1985-2004). Journal of Development Economics. DEVEC-01477. Elsevier.

Gujarati, D. N., \& Porter, D. C. (2009). Basic Econometrics. Singapore: McGraw-Hill.

Guiga, H., \& Rejeb, J. B. (2012). Poverty, Growth and Inequality in Developing Countries. International Journal of Economics and Financial Issues, 2 (4) 470-479.

Hadid, M. F. (2008). Analisis Hukum Islam terhadap Kriteria Miskin dalam Program Asuransi Keluarga Miskin (Askeskin) (Studi Kasus Pelaksanaan Askeskin di Kelurahan Pindrikan Lor Kota Semarang). Semarang: Skripsi UIN Walisongo.

Hajiji, A. (2010). Keterkaitan antara Pertumbuhan Ekonomi, Ketimpangan Pendapatan dan Pengentasan Kemiskinan di Provinsi Riau 2002-2008. Bogor: Tesis IPB.

Hakim, Arif Luqman. (2013). Analisis Faktor-Faktor yang Mempengaruhi Jumlah Penduduk Miskin dan Pandangannya dalam Islam. Bogor: Skripsi STEI Tazkia.

Khaldun, I. (2011). Muqaddimah. Beirut: Daru ihya' wa turaats al 'arabii

Kumalasari, M. (2011). Analisis Pertumbuhan Ekonomi, Angka Harapan Hidup, Angka Melek Huruf, Rata-rata Lama Sekolah, Pengeluaran Perkapita dan Jumlah Penduduk Terhadap Tingkat Kemiskinan di Jawa Tengah. Semarang: Skripsi Universitas Diponegoro.

Kuncoro, M. (2004). Quantitative Method, Theory and Application for Business and Economics. Yogyakarta: UPP AMP YKPN.

Kuncoro, M. (2000). Ekonomi Pembangunan: Teori, Masalah dan Kebijakan. Yogyakarta: UPP AMP YKPN.

Manurung, A. H. (2012). Advanced Statistics Problem. Jakarta: Tarumanegara University

Nachrowi, N.D., \& Usman, H. (2006) Popular Approach and Practicable Econometric for Economics and Finance Analysis. Jakarta: Lembaga Penerbit Fakultas Ekonomi Universitas Indonesia.

Prastyo, A. A. (2010). Analisis Faktor-Faktor yang Mempengaruhi Tingkat Kemiskinan (Studi Kasus 35 Kabupaten/Kota di Jawa Tengah Tahun 2003-2007). Semarang: Skripsi Universitas Diponegoro.

Purnamasari, P. 2013. Analisis Pertumbuhan Ekonomi, Disparitas Pendapatan dan Pengangguran terhadap Kemiskinan antar Provinsi di Indonesia Periode 2005-2009. Bandung: Skripsi Universitas Pasundan.

Putra, D. F. (2014). Analisis Kemiskinan di Negara-Negara OKI (Studi Model Pembangunan Ibnu Khaldun) Bogor: STEI Tazkia.

Qardhawi, Y. (1995). Kiat Islam Mengentaskan Kemiskinan, Cetakan Pertama. Jakarta: Gema Insani Press.

Setiyaningsih, R. F. (2012). Komparasi Kemiskinan Negara Berpenduduk Mayoritas Muslim dan Non Muslim di Asia Tenggara. Bogor: Skripsi STEI Tazkia.

Suharto, E. (2005). Membangun Masyarakat Memberdayakan Masyarakat. Bandung: Refika Aditama. 
Suwiknyo, D. (2009). Kamus Lengkap Ekonomi Islam. Yogyakarta: Total Media.

Todaro, M. P., \& Smith, S. C. (2006). Pembangunan Ekonomi di Dunia Ketiga. Jakarta: Erlangga. Penerjemah: Drs. Haris Munandar, MA; Puji A.L, SE.

UN (2010): World Economic Situation and Prospects 2010. United Nation Publication, New York.

Wang, L. Yao., \& Xin. (2009). China's Rural Poverty Line and the Determinants of Rural Poverty. China Agricultural Economic Review, 1 (3), 283-300 
This page is intentionally left blank 